Article

\title{
Conservation of Beirut's Urban Heritage Values Through the Historic Urban Landscape Approach
}

\author{
Ibtihal Y. El-Bastawissi ${ }^{1, *}$, Rokia Raslan ${ }^{2}$, Hiba Mohsen ${ }^{1}$, and Hoda Zeayter ${ }^{1}$ \\ ${ }^{1}$ Faculty of Architecture-Design and Built Environment, Beirut Arab University, Lebanon \\ ${ }^{2}$ Institute for Environmental Design and Engineering, University College London, UK \\ * Corresponding author (ibtihal@bau.edu.lb)
}

Submitted: 30 July 2021 | Accepted: 11 October 2021 | Published: 23 February 2022

\begin{abstract}
Cities are complex urban systems with dynamic transformations in their socio-economic and environmental dimensions. Several studies have shed light on the fragility of the urban heritage and the strategies of its conservation. The historic urban landscape (HUL) approach is a new framework adopted by UNESCO to deal with urban heritage. This article aims to apply the HUL approach to the rehabilitation and management of Beirut historic neighbourhoods impacted by the massive Beirut port explosion, focusing on Armenia Street in the Mar Mikhael neighbourhood as a case study. The application of the HUL framework allows for the re-evaluation of heritage not as an individual physical form but as an urban fabric interconnected to the city, inclusive of its cultural, social, architectural, and urban layers. The article investigates the application of the four tools identified within HUL recommendations-(1) regulatory systems, (2) community engagement, (3) planning, and (4) financial tools-by proposing implementation strategies in the assessment of urban heritage to mitigate major risks. The result reveals that cooperative efforts among private and public stakeholders can play a vital role in the development of Beirut heritage, acting as catalysts for urban heritage conservation. Strategies for establishing a new legislative framework that is focused on protecting Lebanese cultural heritage and ensuring sustainable adaptation planning are highlighted.
\end{abstract}

\section{Keywords}

Beirut; collaborative tools; historic urban landscape; intangible heritage; tangible heritage; urban lab

\section{Issue}

This article is part of the issue "Urbanisation, Crisis, and Resilience: The Multiple Dimensions of Urban Transformation in Beirut, Lebanon" edited by Liliane Buccianti-Barakat (Saint Joseph University) and Markus Hesse (University of Luxembourg).

(C) 2022 by the author(s); licensee Cogitatio (Lisbon, Portugal). This article is licensed under a Creative Commons Attribution 4.0 International License (CC BY).

\section{Introduction}

In modern conservation practice, the consideration of the "urban dimension" is essential to properly debate the limitations of the traditional architectural conservation principles. Beirut, a city that has been burdened by several urban development issues, including uncontrolled urbanisation and lack of infrastructure, and multiple crises, such as economic crises, political unrest, and the massive port explosion, is selected as a case study for the application of the historic urban landscape (HUL) approach. The city epitomises the dilemma of heritage protection under the guidelines mentioned in "The UNESCO Recommendation on the Historic Urban Landscape" (World Heritage Training and Research Institute for the Asia and the Pacific Region, 2016), which include a comprehensive approach in understanding historic areas as dynamic multi-layered structures including cultural and natural attributes as well as preserving the quality and sustainability of the built environment while promoting their social and functional diversity. The HUL approach was defined in the Vienna Memorandum 2005 and adopted by UNESCO and the World Heritage Centre in 2011 to identify new urban 
conservation tools that contribute to the conservation of urban heritage values through an innovative toolkit (Bandarin \& van Oers, 2012). Amongst other principles, the HUL approach relies on collaborating with the community in conservation efforts and developing strategies within an adequate regulatory and financial framework, intending to protect the integrity and authenticity of the heritage context in its tangible and intangible forms.

In Beirut, the priority in protecting the heritage core of the city has shifted towards integrating heritage buildings and assets into the modern functions of the city; however, the established debate between the conservation of heritage and its unavoidable and necessary adaptation to the new requirements remains an issue. Furthermore, this tension has been further complicated by the August 2020 Beirut port blast, which has had a catastrophic impact on the city's urban heritage. Within this challenging context, this study aims to assess the potential of the implementation of the HUL framework within the context of the case study of Armenia Street in Beirut's Mar Mikhael neighbourhood to identify opportunities to achieve sustainable urban heritage conservation through effective community engagement. To achieve this goal, the study objectives include the definition of HUL principles and tools, highlighting relevant local and regional examples, the analysis of the current Lebanese urban policies, their impact on the status of the city's urban heritage, and the port blast as an inflexion event. Moreover, it examines the applicability of the HUL approach in the context of Beirut's urban heritage, identifies the challenges facing implementation in the post-disaster situation, and suggests ways to implement HUL tools that address the identified challenges. The article also demonstrates its applicability through an urban design intervention focused on the case study area of Armenia Street.

\section{The Historic Urban Landscape Approach: Definition and Principles}

The HUL approach represents a fresh understanding of the historic environment as "it provides the basis for integration of urban conservation within an overall sustainable development framework through the application of a range of traditional and innovative tools adapted to local contexts" (World Heritage Training and Research Institute for the Asia and the Pacific Region, 2016, p. 11). In addition to natural disasters, regional conflicts, and the lack of management capacity, any urban development or regeneration project can adversely impact heritage sites (van Oers, 2010). The HUL approach provides a means by which to respond to the need to improve the management process and enable the sustainable conservation of heritage urban contexts that face these aforementioned challenges (Taylor, 2015). It achieves this by providing a set of solutions to resolve planning problems within historic contexts without "freezing" heritage sites (Roders, 2019). According to the HUL approach, cities should establish the most fitting procedures and utilise the most appropriate techniques and solutions that suit their context. The common principles of the HUL approach most commonly identified in the previous ten years of its application as described in Roders (2019) include activities that involve elements of identification, integration, and prioritisation, underpinned by participation and partnerships (Roders, 2019). Specifically, identification encompasses the undertaking of surveys and mappings of the city's natural, cultural, and human resources and the subsequent identification of which values and characteristics should be conserved through participatory planning and stakeholder discussions. Based on this, the degree to which these characteristics are vulnerable to socioeconomic stressors is determined. Integration aims to ensure that urban heritage values and their vulnerability conditions are then included in the broader framework of city urban planning to prioritise the conservation of areas of heritage sensitivity that demand specific attention concerning planning, design, and execution of development projects. This process is underpinned by the establishment of partnerships and local management structures for the specified conservation and development projects, along with management procedures for the diverse set of activities between public and private players.

In demonstrating the applicability of the HUL approach, 28 case studies with different contexts were analysed in the book Reshaping Urban ConservationThe Historic Urban Landscape in Action (Roders \& Bandarin, 2019). An example in the Lebanese context (Tripoli) highlighted the morphological structure of the urban river corridor as an integral part of the heritage of local inhabitants and the necessity to update the existing regulations (Ginzarly \& Teller, 2019). Another regional case study took the tangible and intangible values of Aleppo city in the context of post-conflict reconciliation (Alsalloum, 2019). Moreover, NAHNOO (a youth-led non-governmental organisation in Lebanon) conducted a study focusing on the urban transformations of the Beirut neighbourhoods of Achrafieh and Mar Mikhael and the conservation of their cultural heritage (Aoun et al., 2020). Adopting the HUL approach, this report highlighted the importance of the economic and social diversity of the Mar Mikhael neighbourhood. In the case of Tripoli, the development of a strategy aiming to conserve natural heritage is highlighted, while in the last-mentioned example the social and economic aspects were mainly adopted to approach the HUL recommendations in Beirut. In this article, the constraints of the urban planning development in Beirut are identified and their impact on the implementation of sustainable heritage conservation is investigated.

\section{Beirut: The City Context and the Complexity of Its Urban Heritage}

Historically, Beirut was a small Phoenician port with little strategic importance. It grew during the Hellenistic 
period, becoming a large and significant Roman city and military base during the fifth century (Salam, 1998). At the end of the 19th century, Beirut became a vilayet under Ottoman rule. After World War II, the city remained an important port for the French Mandate territories characterised by slow urban growth.

Beirut has a rich urban heritage that dates back to Ottoman and French Mandate periods. The current Lebanese conservation laws date back to 1933 and only conserve monuments built before the 1700 s. As Beirut's 1954 Master Plan concentrated high densities in the historic centre, this hampered the effort to conserve the remaining heritage. Moreover, the latest modifications to the Lebanese building regulations (especially 2004) further intensified pressure on this vulnerable urban fabric by increasing the allowable total exploitation of land to maximise real estate development profit (Mohsen et al., 2020).

During the civil war reconstruction, many heritage buildings were destroyed or threatened with complete demolition. Most recently, the 2020 Beirut blast resulted in the damage of more than 640 historic buildings (UNESCO World Heritage Convention, 2020). In post-war settings similar to that of today's Beirut, a redrafting of the conservation practices is essential to better address current political, cultural, and economic realities while also considering the attitudes of numerous stakeholders concerning modernity, national identity, and authenticity (Saliba, 2013).

\subsection{The Urban Heritage of Beirut and Conservation Laws}

Lebanon still lacks proper legislation that protects built heritage. The main regulation is the outdated 1933 High Commissioner decision on antiquities (Ashkar, 2018). The first clause in the 1933 Lebanese Antiquities Protection Law No. 166 declares that any building constructed before 1700 is considered an antiquity, automatically registered in the General Inventory of Historic Monuments, and protected from demolition and degra- dation. However, this law has a very narrow perspective in defining and classifying the built heritage and in protecting the heritage urban fabric. As a result, only 75 buildings out of a total of 500 buildings in this inventory are in Beirut; thus, most of the built heritage in the capital city remains unprotected and subject to several threats.

In 1995, concurrently with the establishment of the Lebanese Company for the Development and Reconstruction of Beirut Central District s.a.I. (Solidere), the minister of culture instructed the Association for the Protection of Sites and Ancient Houses to list all the buildings built before 1945 on the perimeter of the city centre to protect them and prohibit their demolition. Consequently, 1,016 buildings were listed in Beirut neighbourhoods located in the peripheral area of the central district, which included Mina El Hosn to Medawar, via Zokak el Blat, Bachoura, Saifi, part of Moussaytbeh, Ras Beirut, Rmeil, and Achrafieh neighbourhoods. This inventory was protected from demolition by the 1996 Decree No. 1879. The following year, investors and developers working in the periphery of the central district lobbied to revise this listing, reducing the inventory by 531 buildings. The argument adopted was that as these buildings were standalone; the new recommendation to conserve all historic buildings constituting a street or a district did not apply. This was a turning point that empowered developers to request the re-classification of what was considered "built heritage," thus designating buildings in categories $D$ and $E$ as not being of sufficient heritage character. However, under the terms of the 2010 Decree No. 57, the Council of Ministers maintained the freezing of the demolition of the 209 heritage buildings listed in categories A, B, and C. Table 1 shows the heritage buildings classification criteria in Beirut and the number of protected buildings in Beirut.

A new conservation law was submitted to the Parliament's General Assembly for issue in 2017 but has remained postponed until now. This new law aimed to ensure fairness for building owners while placing responsibility on the state to protect monuments, edifices, buildings, and heritage installations that are isolated

Table 1. Beirut heritage building classification criteria.

\begin{tabular}{|c|c|c|c|}
\hline Year & $\begin{array}{l}\text { No. of Protected } \\
\text { Heritage Buildings }\end{array}$ & Law or Decree & Classification Criteria \\
\hline 1933 & 75 & Law No. 166 & Constructed before the year 1700 . \\
\hline 1996 & 1,016 & Decree No. 1879 & Constructed before 1945. \\
\hline 1998 & 485 & & Built before 1945 , located in a cluster of heritage urban fabric. \\
\hline 2010 & 209 & Decree No. 57 & $\begin{array}{l}\text { Categories } A, B \text {, and C: } \\
\text { A - High significance and contributing to patrimonial culture heritage; } \\
\text { B - High architectural value, illustrating a type, a period, or } \\
\text { a construction method, and they are in good condition; } \\
\text { C - High architectural value, illustrating a type, a period, or } \\
\text { a construction method, but they need several interventions } \\
\text { to rehabilitate or maintain. }\end{array}$ \\
\hline
\end{tabular}


or that form an urban fabric through the "Transferring the Development Rights" programme (Khechen, 2018). Nevertheless, the new law still falls short in terms of addressing the many concerns of heritage advocates, as it does not address modern-era or intangible heritage (UN-Habitat, 2018).

\subsection{The Beirut Port Blast}

The reconstruction of Beirut's port and the damaged surrounding areas represents an opportunity to reformulate and adopt new approaches in conserving the remaining urban heritage in Beirut. The consideration of these historical areas as economic and social assets constitutes a basis for establishing local policies for the management of tangible and intangible heritage to achieve sustainable development. Following the Beirut port blast and within the context of the economic crisis, Law No. 194 was issued in response to the urgent need to protect Beirut's historical heritage landmarks. This aimed to protect the damaged areas and facilitate their reconstruction, by putting the affected area under study, stopping the consolidation of plots, and freezing building permit approvals (and real estate development) for two years subject to renewal (The Embassy of Lebanon, 2020). In the current context and specific post-catastrophic conditions, there is a need for a new classification model to re-assess the built heritage surrounding the Beirut Central District. This assessment depends not only on the architectural significance of the building presented by its type, morphology, construction system, and materials, but also on its state of conservation. Another important indicator is the existence of "group value," which denotes the importance of the heritage building in its surrounding urban fabric.

\section{Application of HUL Within the Beirut Context}

The HUL approach offers a framework that enables the consideration of the complex issues identified within the Beirut context. This section aims to discuss the four tools (Figure 1) identified within the 2011 HUL recommendations, highlight the challenges in applying them, and develop an action-based programme to implement them in Beirut.

\subsection{The Regulatory System}

Regarding the regulatory system in Lebanon, Table 2 summarises the urban planning regulations and construction, municipal, and rental laws that directly impact the heritage context in Beirut (World Bank, 2003).

In analysing the applied laws, the shortcomings identified include outdated planning regulations that do not suit modern planning requirements, building codes that do not sufficiently consider the characteristics and condition of heritage buildings when regulating building heights and setbacks, and municipal laws that do not incentivise tenants and residents to value conservation through methods such as reducing taxes or promoting economic and social co-benefits.

\subsection{Knowledge and Planning Tools}

Mapping and documentation tools play an important role in aiding planning. Collecting data, detailed

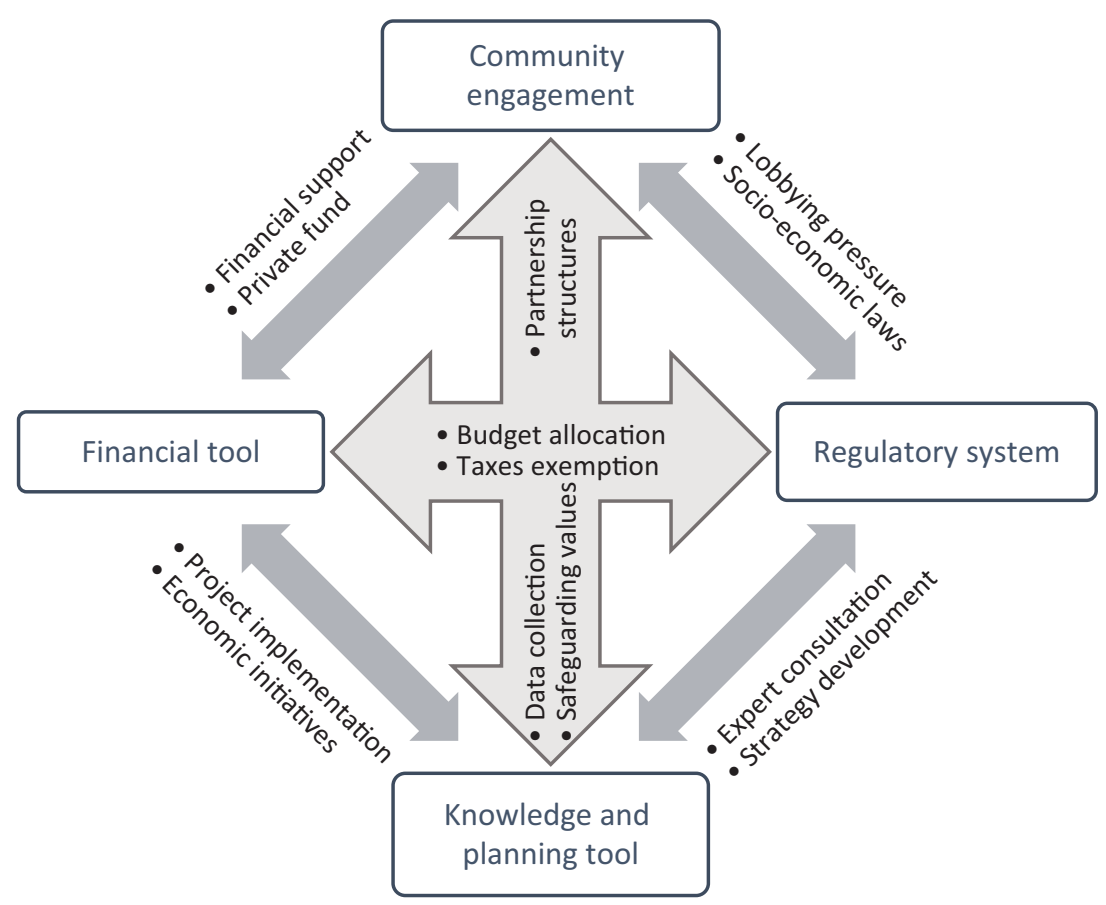

Figure 1. Interrelation between 2011 HUL recommendation tools and the context of Beirut. 
Table 2. Lebanese regulations with direct impact on Beirut's urban heritage.

Urban Planning Regulations

(Decree/Law No. 69 of

September 1983)

Construction Law

(Law No. 646 of 2004)

Municipal Law

(Decree/Law No. 118 of 1977)

Rental Law

(The "Old" 1945 Rent Law and

Rent Acts No. 159 and 160 of

1992)
Elaborate plans and regulations for the historic sites that are responsible for delimiting the districts which must be conserved or developed.

The construction law is important in the conservation context as it regulates the appearance and structural integrity of buildings.

It gives the municipalities the responsibility of ordering owners to rehabilitate and restore buildings at their expense and controlling infringement on regulations.

The new rental law in 1992 allows periodic revisions of rents. However, most rented residential and commercial divisions in historic buildings in Beirut have contracts that are mostly older than 1992. Thus, most rents are fixed at a very low price, which discourages refurbishment initiatives from both owners and tenants.

Source: Adapted from World Bank (2003).

surveying, and GIS-based mapping coordinate visual data and capture the visual morphology of the city. While the use of this kind of urban heritage mapping in Beirut is still in its infancy, there is an urgent need for detailed and updated surveys and mappings of the city's natural, cultural, and human resources. In particular, Beirut contains significant modern built heritage (from the 1960s) that should be included in the urban heritage conservation plans but is yet to be recorded (Tabet, 1998).

\subsection{Community Engagement}

The stakeholders involved in the Beirut Heritage Conservation Plan are defined as public and private groups. The two most influential public stakeholders are the Directorate General of Antiquities (DGA) and the Municipality of Beirut. The DGA, under the Ministry of Culture, has the mandate to protect and conserve national heritage, including maintaining sites and buildings and overseeing and undertaking research and excavations. Despite attempts to save the damaged built heritage after the port explosion, shortcomings in the human, financial, and logistical resources of the DGA remain a significant obstacle in managing the conservation process.

The private stakeholder group involves experts working in academia and in practice, as well as in consultancy and advice, such as the Lebanese universities, the Order of Engineers and Architects, urban planners, conservationists, craftsmen, and specialists in vernacular architecture. This group is capable of communicating and establishing links at various levels and has the flexibility to respond to the encountered challenges. In addition, the community-based groups are considered as private stakeholders who are in contact with the heritage resources on a daily basis, e.g., owners, residents, and users. It also includes developers/private sector, with an (economic) stake in the heritage resource (Roders, 2019).

The World Heritage Committee (2013) implemented five recent projects in Lebanon aiming to conserve urban heritage listed as world heritage sites. These projects identified an insufficient level of coordination and com- munication among stakeholders, mainly due to the lack of human resources at the DGA main and regional offices. However, following the port explosion, the participation of the private sector stakeholders in the efforts to safeguard the built heritage in Beirut was considered to be highly efficient and enabled positive collaboration with administrative institutions.

Further examples of successful collaboration and empowerment initiatives can also be identified. The first is the Order of Engineers and Architects' workshops, where experts and administration representatives collaborated with citizens to establish a process of negotiation before decisions were taken to reconcile points of view. The Order of Engineers and Architects, in collaboration with several faculties of architecture in Lebanon, then produced the Beirut Urban Declaration, which lays out a broad vision for methods to reform and improve afflicted regions. These included focusing on the conservation of heritage urban fabric, considering the afflicted area's heritage character, identifying priorities for interventions, and establishing an observatory (Order of Engineers and Architects, 2021).

The second is the Beirut Arab University Urban Lab project selected by UNESCO, the UN Population Fund, and the UN Office on Drugs and Crime within the framework to promote youth-led initiatives in response to the Beirut blast (UNESCO, 2020). This aimed to empower citizens to cooperate in urban planning decision-making processes by encouraging children's participation through play using strategically designed cognitive maps of the territory of the Beirut blast in a game environment. One of the activities implemented in June 2021 was the "Beirut Miniature Model Art Exhibition" at St. Nicholas public staircase, which included activities aiming to give children a greater awareness of their local neighbourhoods and a coping strategy after the stressful event.

\subsection{Financial Tools}

In the absence of a clear financial strategy to fund heritage conservation and management projects in 
Lebanon, investment in the conservation of built heritage on a national level is a significant challenge to local administration bodies. This is due to the lack of protection laws in its regulatory system and the lack of financial resources that could be invested in the conservation and maintenance of heritage assets. During the post-war reconstruction phase, Beirut witnessed fast urban growth and limited availability of land. The state actively developed a neoliberal economic development model, focusing on urban areas and especially Beirut, which had defined policies for nearly all successive governments since the 1990s (Ashkar, 2018; UN-Habitat, 2018).

As a result of the 2019 economic crisis, the government established a strategy to reduce its expenditure. This limited the human and financial resources available to the DGA, Beirut Municipality, and all public stakeholders involved in urban heritage development and in turn restricted the national capacity to conserve and manage Beirut's built heritage. The only current mechanism to fund any intervention or project is via co-financing by international governments and institutions, which, in the past decades, have supported projects in five Lebanese cities, which had heritage cores listed in the World Heritage List (World Heritage Committee, 2013).

\subsection{Challenges in Applying the HUL Framework}

A SWOT analysis was undertaken for Beirut in general and the selected pilot study in particular to understand the strengths, weaknesses, opportunities and threats associated with the implementation of the HUL approach and subsequently help inform strategies for future urban development (Table 3).

Within the context of each of the abovementioned areas, the main challenges facing the establishment of a sustainable urban heritage conservation strategy in Beirut are the efficacy of public administration and the agencies assigned the task of monitoring the management of Lebanese territories and ecological resources (Salam, 1998). Since the end of the civil war in 1990, the government has listed properties as

Table 3. SWOT analysis for HUL application in the context of Beirut and the selected street.

\begin{tabular}{|c|c|c|}
\hline & Beirut & Armenia Street \\
\hline \multirow[t]{2}{*}{ Strengths } & $\begin{array}{l}\text { The multicultural diversity of the inhabitants } \\
\text { indicates positive interaction with and } \\
\text { acceptance of unconventional urban } \\
\text { interventions and new landscape settlements. }\end{array}$ & \multirow[t]{2}{*}{$\begin{array}{l}\text { Location of the urban heritage core in the areas } \\
\text { that have economic and cultural potential, and } \\
\text { that could be adapted into any new } \\
\text { development strategy. }\end{array}$} \\
\hline & $\begin{array}{l}\text { Designation criteria: Outstanding universal value } \\
\text { of many significant landmarks and heritage } \\
\text { buildings in addition to the authenticity and } \\
\text { integrity of their heritage value. }\end{array}$ & \\
\hline \multirow[t]{4}{*}{ Weaknesses } & Lack of effective heritage preservation laws. & \multirow{2}{*}{$\begin{array}{l}\text { Funding issues and lack of coordination between } \\
\text { different stakeholders. }\end{array}$} \\
\hline & $\begin{array}{l}\text { Lack of efficacy of public administration } \\
\text { and agencies. }\end{array}$ & \\
\hline & $\begin{array}{l}\text { Lack of public spaces and green areas in Beirut } \\
\text { makes the implementation of urban } \\
\text { development projects in heritage } \\
\text { neighbourhoods difficult. }\end{array}$ & \multirow[t]{2}{*}{$\begin{array}{l}\text { Private ownership of heritage buildings requires } \\
\text { substantial involvement of inhabitants in the } \\
\text { safeguarding of urban heritage. }\end{array}$} \\
\hline & $\begin{array}{l}\text { Lack of benchmarking and databases of a } \\
\text { national heritage asset. }\end{array}$ & \\
\hline \multirow[t]{2}{*}{ Opportunities } & $\begin{array}{l}\text { Wider interest and focus on safeguarding cultural } \\
\text { heritage after the Beirut port blast by national } \\
\text { experts and many international institutions. }\end{array}$ & \multirow[t]{2}{*}{ Revitalising existing natural patches. } \\
\hline & $\begin{array}{l}\text { Development of a new governance model to } \\
\text { manage the heritage asset in Beirut. }\end{array}$ & \\
\hline \multirow[t]{3}{*}{ Threats } & $\begin{array}{l}\text { The unpredictability of the political situation and } \\
\text { complexity of the current governmental } \\
\text { arrangements prevent the implementation of } \\
\text { new laws and regulations. }\end{array}$ & $\begin{array}{l}\text { Gentrification in Mar Mikhael neighbourhood for } \\
\text { the past decade due to real estate speculation. }\end{array}$ \\
\hline & $\begin{array}{l}\text { Growing threats of pollution and environmental } \\
\text { problems. }\end{array}$ & \multirow[t]{2}{*}{ High-rise buildings replacing historic buildings. } \\
\hline & Investment fuelled land speculation. & \\
\hline
\end{tabular}


protected heritage buildings, without giving their owners any incentives or grants that encourage their conservation. This led owners to successfully petition to delist their heritage properties to allow them to sell them freely to developers, who were likely to demolish them (Zgheib, 2020).

Since the 1990s, real estate capital investment has fuelled land speculation, culminating in real estate booms focused on upscale building developments. Furthermore, gentrification had a significant role in Beirut's urban regeneration and growth (Ashkar, 2018). Concerning the Armenia Street pilot case study, gentrification took place when its main economic activity pattern changed from handmade crafts to restaurants and pubs, which is reflective of the general economic trend in Lebanon over the past two decades (Gerbal et al., 2016). However, in the current climate, even these economic activities are shutting down; thus, there is an even greater need to set new objectives for urban heritage development in the area.

\subsection{Developing a Practical Action-Based Programme to Implement the HUL Framework in Beirut}

The first step towards implementing the HUL approach in Beirut is related to the political establishment. Specifically, it is recommended that the government set up an administrative unit for managing cultural heritage. The organisational structure of this heritage management unit needs to be determined, should ideally be recruited from the pool of public stakeholders involved in urban planning decision making, and should ideally encompass an inter-disciplinary team with proven expertise and experience in such areas as project management, public procurement, architectural design and planning, conservation expertise, and social sciences. The aim of this unit should be to formulate and implement all the relevant actions to conserve urban heritage. The following section presents actions proposed by the authors to implement the action-based programme required to integrate the HUL approach into the post-disaster recovery of Beirut:

- The establishment of regulatory systems that support the need to protect remaining heritage from real estate speculation in Beirut, through the development of new regulations and building laws that protect urban heritage values. This should involve the modernisation of heritage management by expanding the concept of heritage, amending laws, recognising, and encouraging networking of cultures and public participation.

- The integration of community engagement and financial tools that reinforce the need to ensure support for local authorities through capacity building, financial support, and employment of technical expertise. The law allows for the establishment of technical offices at municipal lev- els (UN-Habitat, 2018). Since Beirut municipality has a technical office, it is recommended to sustain it and support its role by ministries, such as the Ministry of Interior and Municipalities or the Ministry of Public Works and Transport. This should strengthen transparency in decisionmaking processes to achieve positive community engagement through informative and collaborative methods. Moreover, supporting small scale urban interventions (also known as "urban acupuncture") that promote liveability in strategically selected areas and encourage participatory initiatives aims to increase involvement of communities and capacity building, which places people at the centre of projects (UNESCO, 2013).

- The implementation of knowledge and planning tools that include the reinterpretation of urban heritage values by including measures that protect modern heritage and the establishment of an independent commission to conserve Beirut urban heritage. Additionally, undertaking surveys, inventory, and documentation of buildings and landmarks of historical, artistic, religious, scientific, architectural, handicraft value, and popular markets are the basis for conserving the urban fabric in a clear policy. Furthermore, the establishment of a new master plan for Beirut, with a holistic vision that applies to all districts, establishes their relation to the port, the function of this port, and their relation to the Beirut Central District. Several points should be considered in its formulation: A general policy based on the right to conserve the private property of residents and secures financial funds that allow the rehabilitation and conservation of property should be adopted and governed by the local administration and public institutions. Urban heritage must be included in the process of economic development, furthermore, the promotion of resilience through integrating cultural activities and the creative industries into the planning, financing, and implementation of post-disaster recovery action plans should be undertaken (Hamad, 2021).

\section{Application of the HUL Approach in the Armenia Street Pilot Study}

Armenia Street is located in the Mar Mikhael neighbourhood near the Beirut Central District. It extends from the Electricité du Liban building from the West passing through Mar Mikhael Station until the Beirut River to the East. The historical buildings on the street are remnants of an affluent residential neighbourhood that dates back to the late Ottoman and French Mandate periods (Figure 2). In the early 1920s, it became a destination settlement for Armenian immigrants. Before that, it had also included small old industrial workshops for crafts, carpentry, and metal work (El Samad, 2016). 


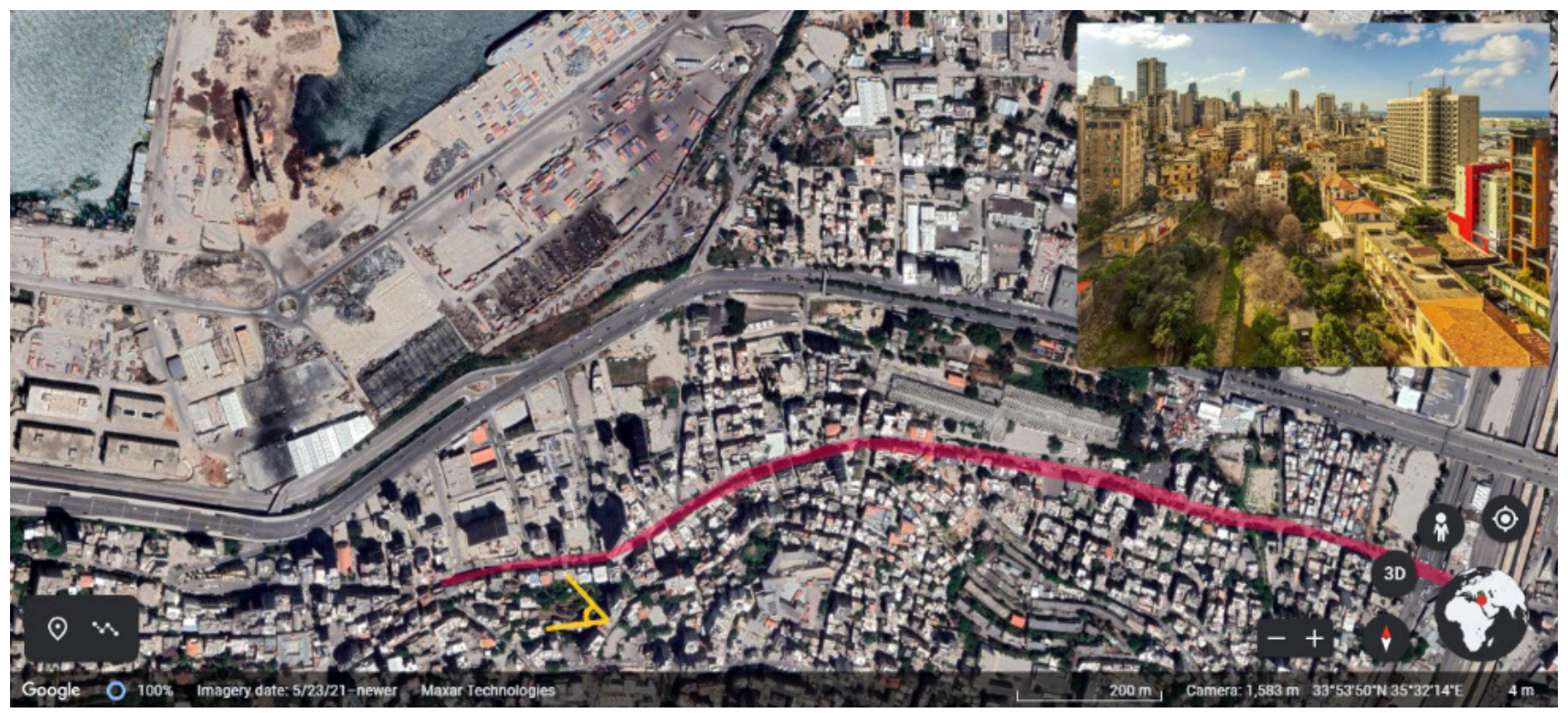

Figure 2. Aerial view of the east end of Armenia Street. Source: Adapted from Google Earth and Mrad (2020).

Over the past decades, art galleries, restaurants, and pubs have replaced the small old industries and businesses that previously characterised the area. Since then, the street has attracted a younger demographic and has evolved to become a vibrant nightlife spot. Real estate developers took advantage of the high-density exploitation factor allowed in the building code, changing the neighbourhood character and replacing old buildings with high-end towers, furthermore contributing to the gentrification of the area, the displacement of residents, and exacerbating a shortage in affordable housing (Ashkar, 2018). Nevertheless, Armenia Street still maintains its identity characterised by the continuous rows of historical buildings of similar heights and setbacks.

\subsection{Threats, Risks, and Damage Assessment}

As discussed above, many historical buildings have been lost and replaced with high-rise buildings due to the absence of heritage protection laws and policies. Heritage buildings are also threatened by the new transportation infrastructure. An example of a project that was refused by many activists is Fouad Boutros highway, which was set to cross Armenia Street, destroy 28 heritage landmarks, and fragment the remaining green spaces.

Following the Beirut port blast, the surviving historical buildings were regarded at risk of collapse, potentially displacing thousands of residents. Figure 3 identifies four damage assessment levels published in the Order of Engineers and Architects weekly survey, illustrating a large number of heritage buildings along Armenia Street. The map highlights the lots containing heritage buildings, indicating that these lots are mainly classified as having buildings in need of immediate structural strengthening and/or on-site structural strengthening rather than isolation or evacuation.

\subsection{Natural and Cultural Assets}

Armenia Street is characterised by its connection to higher areas through several public stairs and passages that create an important heritage asset for pedestrian networks and have the potential to revive abandoned spaces by reintegrating them into the urban fabric of Mar Mikhael (Figure 4). Beirut has been losing its green spaces at a dramatic rate during the past decades due to rapid urbanisation and currently has only $0.8 \mathrm{~m}^{2}$ of green space per capita compared with the recommended minimum of $12 \mathrm{~m}^{2}$ per capita by the World Health Organization. The remaining green patches in this area, scattered throughout the street and backyards of the old buildings, are fragmented but particularly significant. Figure 5 illustrates the mapping of the main existing trees in the selected pilot study classified according to their type and based on a field survey conducted in 2021. One of the few studies evaluating how green infrastructure can reduce the effects of climate change in Beirut's peri-central districts revealed the type of trees that can improve the pedestrian thermal comfort level during the hot summer days. It correlated between the vertical distribution of leaf area density and physiological equivalent temperature values (Mohsen et al., 2016). Moreover, community gardens and edible landscapes can play a crucial role not only in creating "sustainable cities and communities" (UN, 2020a), as mentioned in the SDG 11 adopted by the UN in 2015, but also as contributors to "ensure healthy lives and promote wellbeing for all at all ages" (SDG 3; UN, 2020b). Green Infrastructure consequently mitigates the urban heat island effect, minimising the energy consumption and pollution emissions related to food transportation, and promotes physical activity.

Integrating natural with cultural and tangible with intangible attributes forms the basis of the HUL 


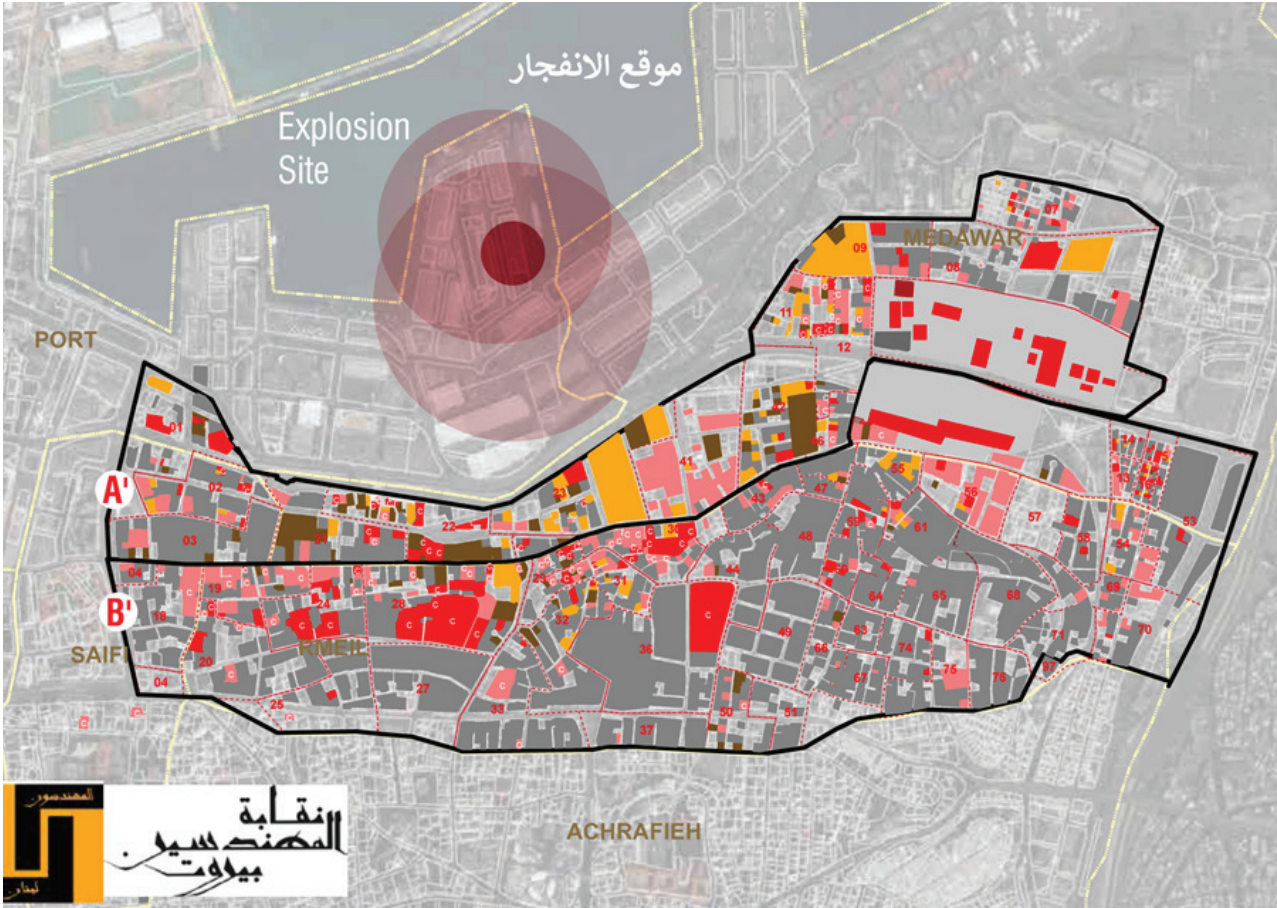

Legend

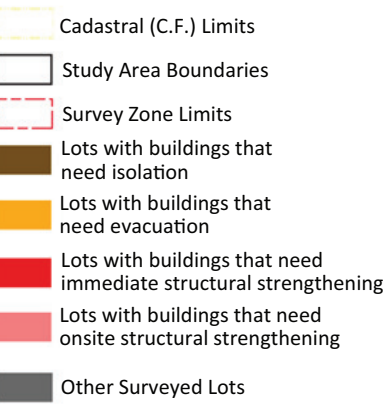

C: Lots containing Heritage Buildings

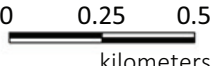

Date: 09/09/2020

Figure 3. Beirut explosion: Weekly structural assessment report. Source: Order of Engineers and Architects (2020, p. 10).

approach; it is thus important to assess the intangible heritage of Armenia Street to regenerate the threatened area. According to the GAIA-heritage surveys (MEDNETA, 2015), small arts, crafts, and design industries are facing challenges due to the increased number of new restaurants and bars, as well as the real estate speculation since 2008 . The study undertaken by Buccianti-Barakat and Hariri (2015, pp. 32-42) highlighted Mar Mikhael resident perceptions of arts, crafts, and design, and recreational activities. The survey found that the older population was very sensitive to changes that affect their traditional environment. However, in sectors to the north of Armenia Street, residents seemed less affected by the noise pollution of restaurants and pubs.

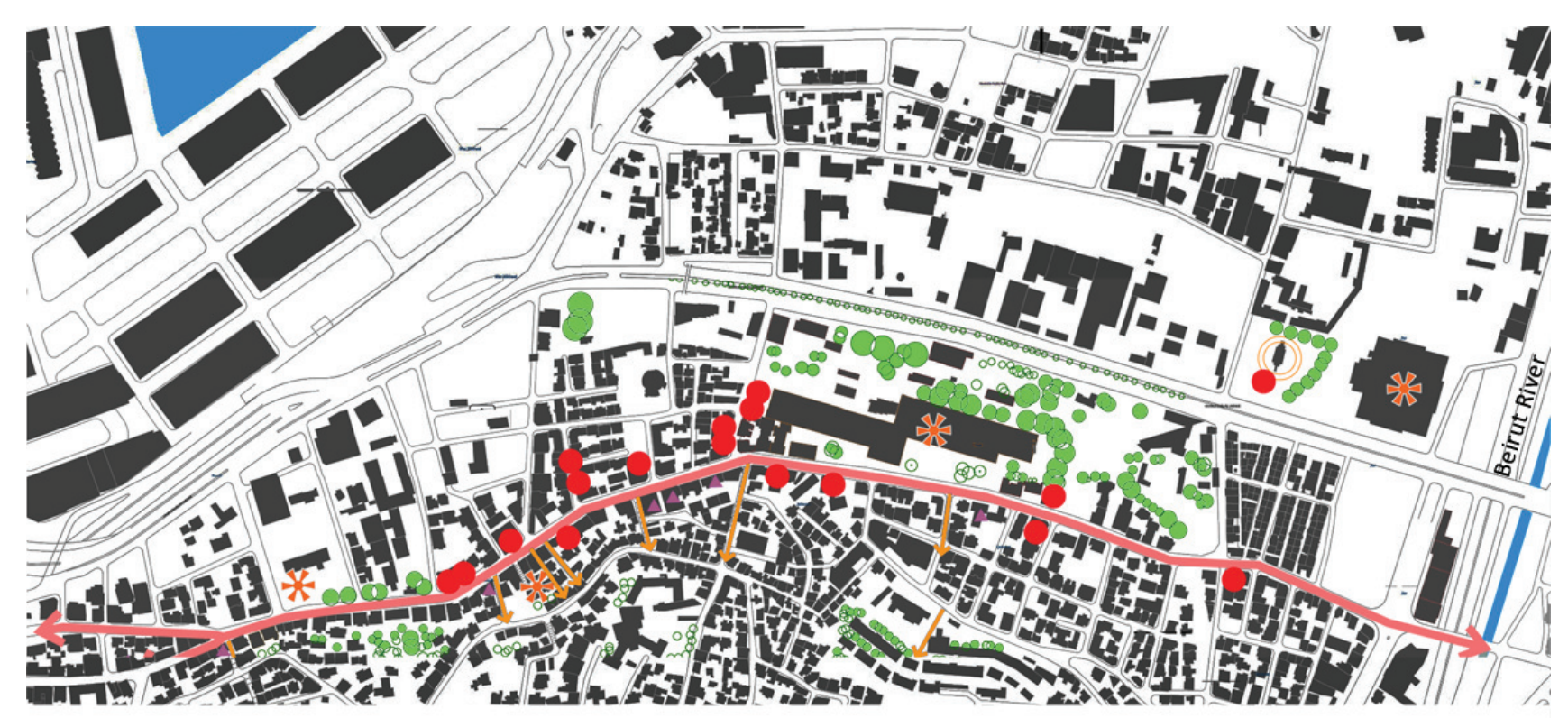
$\longleftrightarrow$ Armenia Street
* Landmarks
$\odot$ Trees
Crafts \& Art
$\longrightarrow$ Public stairs
Restaurants and Pubs

Figure 4. Commercial and cultural activities in Armenia Street. 


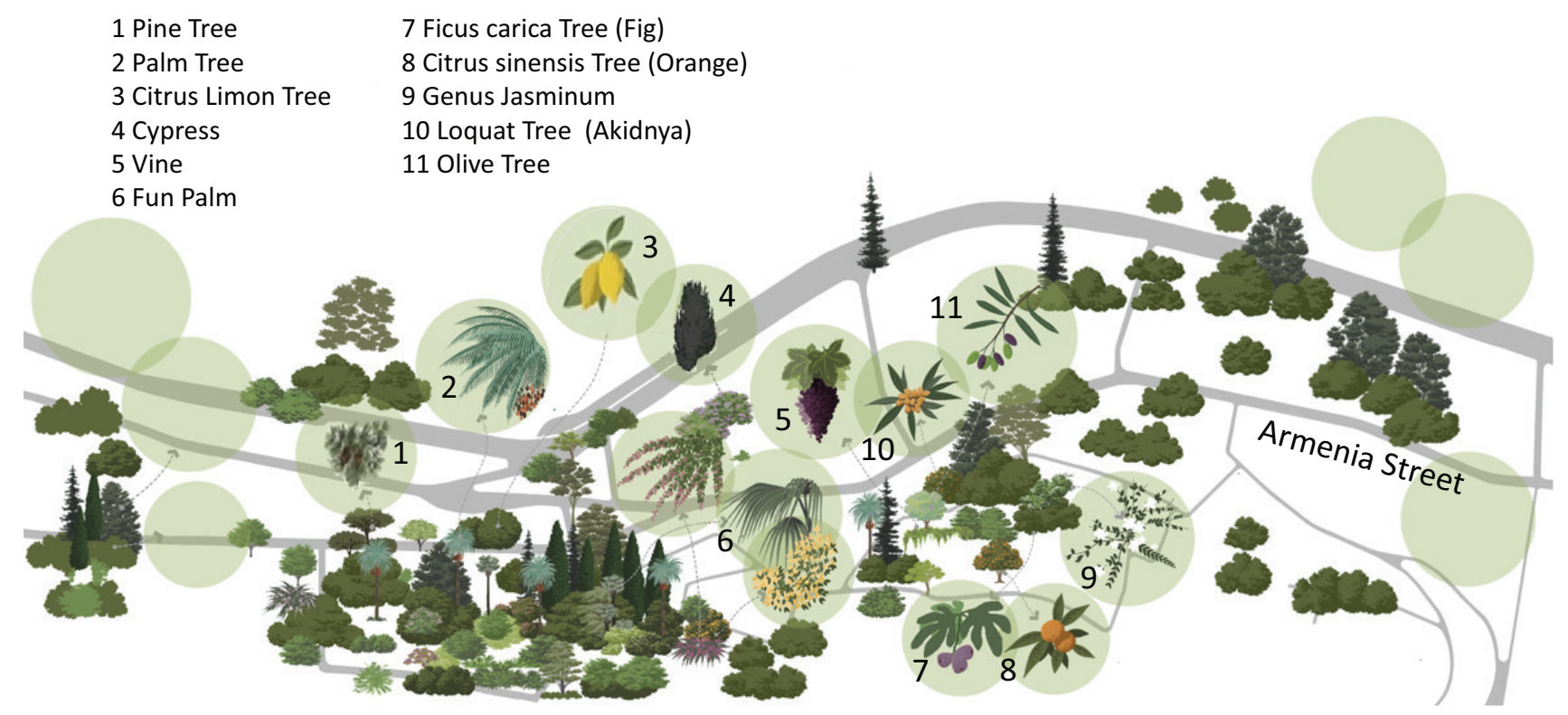

Figure 5. Existing natural assets surrounding Armenia Street: 2021 field survey. Source: Beirut Arab University Urban Lab (2021).

\subsection{Proposed Urban Intervention}

Following a socio-spatial analysis of the current situation, informed by the analysis described in Section 4 of this article, HUL recommendations were applied to Armenia Street to inform the formulation of an urban intervention for the area. This utilised the set of HUL tools, the two main ones being the regulatory and planning tools, where the mapping of the built heritage, natural assets, and economic and cultural activities in the street, in addition to the analysis of the regulatory system, were used to identify the challenges and threats facing urban heritage streets.

Following this, a consultation process with residents highlighted the priorities that the intervention should aim to address. Semi-structured interviews were conducted on 20 residents in Armenia Street to assess their socio-economic attributes as well as the reasons behind their attachment to the place and to understand whether they prefer to keep their building as it was before reconstruction commenced or if they are indeed flexible to changes such as the internal and/or external architectural details and materials. Moreover, during the survey, residents were asked about their willingness to improve the outdoor open spaces with a focus on the need to improve the pedestrian infrastructure.

This investigation covered 10 heritage buildings that were damaged due to the port explosion. It turned out that four of these buildings had not been restored and their residents had not returned to them after the explosion. In the absence of official statistics about the occupants of these buildings and their conditions, it will be difficult to determine the priorities of restoration by the official authorities and concerned associations. The interviewed inhabitants stressed the importance of the safe return of the residents who were displaced due to the explosion, and their fears due to the uncertainty of the preservation of their right to return to their rented homes due to the old rental law, especially Law No. 194 which protects them for one year only, where the lease contracts were extended for a full year from the date of publication of the law, that is, until October 22nd, 2021. As a validation of their concerns, Beirut Evictions (beirutevictions.org), a website dedicated to documenting and mapping the fate of old-rent buildings, shows the high rate of eviction in the past ten years in the Beirut neighbourhood.

The findings also revealed the need for economic incentives to maintain the heritage of the buildings and to encourage owners to preserve their lots/buildings, as well as to protect them from real estate speculation.

The resulting proposed urban intervention (Figures 6 and 7) focuses on the spatial and functional connectivity with the surrounding fabric by reconnecting the alleys between the buildings, existing public staircases, and remaining green areas, as well as proposing paths to restitch the street with the port and surrounding neighbourhoods. The main features include:

- Reconnecting the street with the Beirut waterfront through Fouad Boutros Street and by creating pedestrian bridges above Charles Helou highway;

- Adding trees to create a green network by reconnecting the existing green patches and promoting edible urban gardens; 


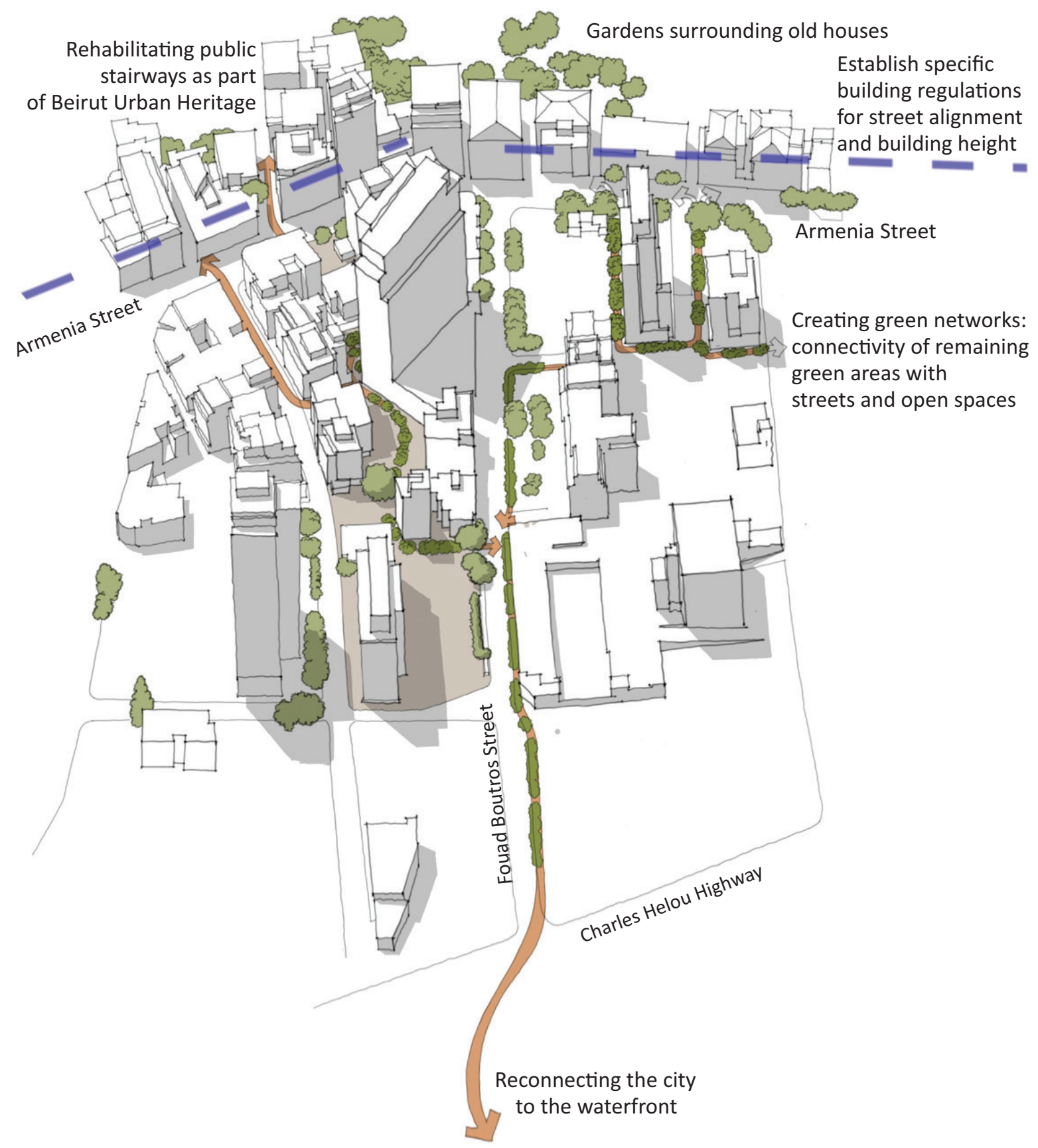

Figure 6. Proposed urban interventions in Armenia Street. 

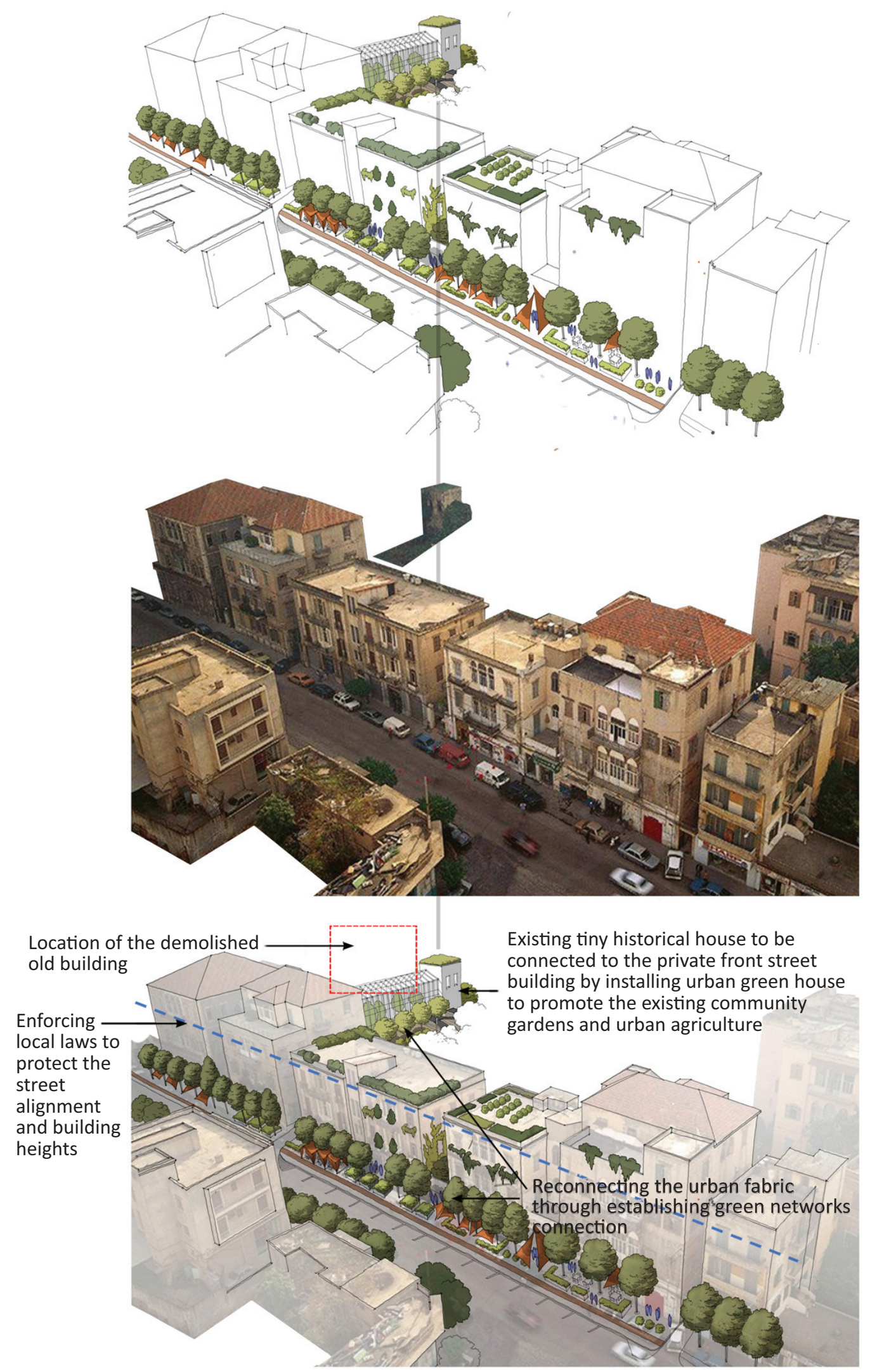

Figure 7. Proposed street interventions. 
- Preserving the tangible and intangible values of heritage buildings;

- Improving the walkability and quality of pedestrian pathways by creating shading areas and improving the liveability of the street;

- Rehabilitating public spaces, especially the heritage stairways for community-centred activities and events;

- Revising building laws to incorporate Armenia Street (and all Beirut heritage streets) within a designated planning zone, where regrouping of parcels is forbidden in order to avoid the construction of high-rise towers, and limiting maximum heights to maintain the heritage fabric.

\section{Conclusions}

While the HUL approach aims at a long-term sustainable urban heritage development, current short-term conservation action plans to assist recovery plans all focus on the structural stabilisation of damaged buildings. Adopting the HUL approach adds to the uniqueness of the area's urban fabric and can uphold its environmental integrity by improving the liveability of urban settings impacted by climate change, urbanisation, amongst other issues. Beirut's intangible heritage, such as traditional cultural activities and daily inhabitants' experiences and behaviours, is considered a resource and can contribute to its urban heritage's rehabilitation and development through powerful community engagement and innovative interventions.

In applying the HUL framework to Beirut, the overall findings can be summarised as follows:

- The conservation of the historic value of a heritage site is in large part influenced by the transparent and effective involvement of residents in heritage management. This is demonstrated in the small interventions proposed in the pilot study in this article, which highlights that the contribution of private owners of built heritage is essential to achieving a more considered evolution of the streetscape of Armenia Street;

- Investment in cultural heritage through conservation, adaptive reuse of cultural heritage assets, and tax incentives should be encouraged;

- Current regulations have failed to safeguard surviving green spaces from aggressive real estate development. Nonetheless, remaining green patches can contribute to the formation of a green network, which may be strengthened by planting trees parallel to roadways and pavements.

The findings of the analysis of the selected pilot study have significant policy implications in the wake of the post-blast reconstruction processes as they demonstrate how the defined set of tools can be used to develop solutions to overcome the challenges encountered.
In the case of Armenia Street, the steps to establish an effective urban conservation strategy that adopts the HUL approach are as follows:

1. To conduct natural, cultural, social, and architectural surveys and mapping of the area;

2. To analyse the data collected to identify and define the neighbourhood's significant assets and values and the challenges and problems facing their conservation;

3. To apply a decision-making process to prioritise which values should be conserved through participatory planning and stakeholders' discussions.

It should be noted that while Armenia Street is one piece of mosaic forming the urban pattern of Beirut, this holistic approach should ultimately be applied all over the city and should consider urban heritage values and their sensitivity to the broader city urban plan. The above process should be reflected in a new master plan and a revision of the regulatory system that allows the updating of the building regulations, rental law, and national preservation listing criteria of built heritage. Together with suitable management structures and their funding resources, these will ultimately pave the way for the conservation and development efforts for the heritage streets in Beirut to commence.

In conclusion, while HUL does provide a promising route to balancing urban heritage conservation with sustainable development of historical areas facing processes of urban transformation, its successful application requires a better understanding of the approach and the requirements needed to establish an infrastructure that supports the collection of information and the development of adequate management processes. Municipalities have a crucial role in formulating planning policies to conserve and manage urban heritage by adapting the HUL approach and planning the city's local distinctiveness.

\section{Conflict of Interests}

The authors declare no conflict of interests.

\section{References}

Alsalloum, A. (2019). Rebuilding and reconciliation in Old Aleppo: The historic urban landscape perspectives. In A. P. Roders \& F. Bandarin (Eds.), Reshaping urban conservation: The historic urban landscape approach in action (Vol. 2, pp. 57-77). Springer.

Aoun, C. B., Farhat, M., Ayoub, M., Saad, E., Tarhini, S., \& Mohti, S. (2020). Achrafieh and Mar Mikhael: Youth-Led architectural heritage mapping in Beirut. NAHNOO. http://nahnoo.org/wp-content/uploads/ 2020/01/Ashrafieh-and-Mar-Mikhael-17-aug.pdf

Ashkar, H. (2018). The role of laws and regulations in shaping gentrification. City, 22(3), 341-357. https:// doi.org/10.1080/13604813.2018.1484641 
Bandarin, F., \& van Oers, R. (2012). The historic urban landscape: Managing heritage in an urban century. Wiley.

Beirut Arab University Urban Lab. (2021). Existing natural assets surrounding Armenia Street: 2021 field survey [Unpublished raw data]. Beirut Arab University.

Buccianti-Barakat, L., \& Hariri, N. (2015). The nightlife carousel: Report on the arts, crafts and design sector and urban change in the Beirut district of Mar Mikhael. MEDNETA.

El Samad, D. Z. (2016). Property, housing and processes of gentrification: A case study of the neighborhood of Mar Mikhael (Beirut) [Master thesis, American University of Beirut]. AUB Scholar Works. https:// scholarworks.aub.edu.lb/handle/10938/20892

Gerbal, L., Hrycaj, N., Lavoipierre, C., \& Potasiak, M. (2016). Linking economic change with social justice in Mar Mikhael: Research report. Issam Fares Institute for Public Policy and International Affairs. https:// www.aub.edu.lb/ifi/Documents/publications/ research_reports/2015-2016/20160627_linking_ MarMikhael.pdf

Ginzarly, M., \& Teller, J. (2019). Operationalizing the HUL recommendation in urban river corridors: Challenges and perspectives. In A. P. Roders \& F. Bandarin (Eds.), Reshaping urban conservation: The historic urban landscape approach in action (pp. 511-527). Springer.

Hamad, L. A. (2021). Towards a resilient creative Beirut. DAR. https://dar.com/content/Publications/ PUD/Beirut-recovery-article-4.pdf

Khechen, M. (2018). Muqtarah hemayat almawaqee wal abnia alturatheya fe Lubnan: Ethraa keebar almustathmereen wa daaewat seghar almalekeen lelraheel? [The proposal to protect heritage sites and buildings in Lebanon: Enriching large investors and inviting small owners to leave?]. Legal Agenda. https://tinyurl.com/3w3uvdj6

MEDNETA. (2015). In Mar Mikhael: Event report. GAIAheritage. http://gaiaheritage.com/wp-content/ uploads/2015/04/InMarMikhael.pdf

Mohsen, H., Raslan, R., \& El-Bastawissi, I. (2016, September 14-16). Optimising the urban environment through holistic microclimate modelling-The case of Beirut's pericenter [Paper presentation]. BSO16: Building Simulation \& Optimization 2016, Third IBPSA-England Conference, Newcastle, UK.

Mohsen, H., Raslan, R., \& El-Bastawissi, I. Y. (2020). The impact of changes in Beirut urban patterns on the microclimate: A review of urban policy and building regulations. Architecture and Planning Journal (APJ), 25(1), Article 2.

Mrad, D. [@diamrad]. (2020, March 7). Beautiful Beirut. Who knew that beyond all those gorgeous traditional houses on Mar Mikhael lays this green field. I wonder how long till towers take over. Closeups in the story [Photo]. Instagram. https://www.instagram.com/p/ B9cG1xppmCg/?utm_medium=copy_link
Order of Engineers and Architects. (2020). Beirut explosion: Buildings' weekly structural assessment report (Weekly Report Number 3). https://www.oea. org.lb/Library/Files/news/2020/sep\%202020/ building\%20Weekly\%20Report\%203.pdf?fbclid= IwAROfH4X7Ksp0GdbQMHDypWPmgTY25FFX2 RFruy5rJmOyjR3KVWLBIOaT-VU

Order of Engineers and Architects. (2021). The reconstruction of neighbourhoods hit by the 4th of the August blast within a national perspective for sustainable development policies: Programme of the thematic workshop March 2021. https://www. docomomo.com/wp-content/uploads/2021/03/ OEA-Workshop-March-2021-Final-Programme-1.pdf

Roders, A. P. (2019). The historic urban landscape approach in action: Eight years later. In A. P. Roders \& F. Bandarin (Eds.), Reshaping urban conservation: The historic urban landscape approach in action (Vol. 2, pp. 21-53). Springer.

Roders, A. P., \& Bandarin, F. (Eds.). (2019). Reshaping urban conservation: The historic urban landscape approach in action (Vol. 2). Springer.

Salam, A. (1998). The role of government in shaping the built environment. In P. G. Rowe \& H. Sarkis (Eds.), Projecting Beirut: Episodes in the construction and reconstruction of a modern city (pp. 122-133). Prestel.

Saliba, R. (2013). Historicizing Early ModernityDecolonizing heritage: Conservation design strategies in postwar Beirut. Traditional Dwellings and Settlements Review, 25(1), 7-24. https://www.jstor.org/ stable/23612198

Tabet, J. (1998). From colonial style to regional revivalism: Modern architecture in Lebanon and the problem of culture identity. In P. G. Rowe \& H. Sarkis (Eds.), Projecting Beirut: Episodes in the construction and reconstruction of a modern city (pp. 83-105). Prestel.

Taylor, K. (2015). Cities as cultural landscapes. In F. Bandarin \& R. van Oers (Eds.), Reconnecting the city: The historic urban landscape approach and the future of urban heritage (pp. 179-202). Wiley.

The Embassy of Lebanon. (2020). Law no. 194 on real estate transactions in areas affected by the Beirut port explosion. http://www.lebanonembassyus.org/ 2020/11/05/law-no-194-on-real-estatetransactions-in-areas-affected-by-the-beirutport-explosion

UNESCO. (2013). Summary of the reflection meeting on the implementation of the Recommendation on the Historic Urban Landscape two years after its adoption (HUL+2). whc.unesco.org/document/133228

UNESCO. (2020). Announcement: UNESCO, UNFPA and UNODC joint call for proposals on youth-led rehabilitation efforts to support local communities affected by the Beirut blast [Press release]. https://en. unesco.org/news/announcement-unescounfpa-and-unodc-joint-call-proposals-youth-ledrehabilitation-efforts 
UNESCO World Heritage Convention. (2020). UNESCO rallies international community to safeguard Beirut's cultural life and heritage. https://whc.unesco.org/ en/news/2152

UN-Habitat. (2018). National urban policies programme in Lebanon: Diagnosis report. https:// unhabitat.org/sites/default/files/documents/201907/nup-report_design.pdf

United Nations. (2020a). Goal 11: Make cities inclusive, safe, resilient and sustainable. https://www.un.org/ sustainabledevelopment/cities

United Nations. (2020b). Goal 3: Ensure healthy lives and promote well-being for all at all ages. https:// www.un.org/sustainabledevelopment/health

van Oers, R. (2010). Managing cities and the historic urban landscape initiative-An introduction. In R. van Oers \& S. Haraguchi (Eds.), Managing historic cities (pp. 7-17). UNESCO World Heritage Centre.

World Bank. (2003). Project appraisal document on a proposed loan in the amount of US\$31.5 million to the Lebanese Republic for the cultural heritage and urban development (Report No. 24488-LE). https://documents1.worldbank.org/curated/en/ 618271468757483917/pdf/multiOpage.pdf

World Heritage Committee. (2013). Report on the reactive monitoring mission to the World Heritage site of Tyre (Sour), Lebanon, 8-14 September 2012. https:// whc.unesco.org/en/documents/122874

World Heritage Training and Research Institute for the Asia and the Pacific Region. (2016). The HUL guidebook: Managing heritage in dynamic and constantly changing urban environments. A practical guide to UNESCO's Recommendation on the Historic Urban Landscape. UNESCO. https://unesdoc.unesco. org/ark:/48223/pf0000259684

Zgheib, M.-L. (2020). Beirut post-blast recovery towards an inclusive housing sector. DAR. https://dar.com/ Content/Publications/PUD/Beirut-RecoveryArticle\%202-26112020HR.pdf

\section{About the Authors}
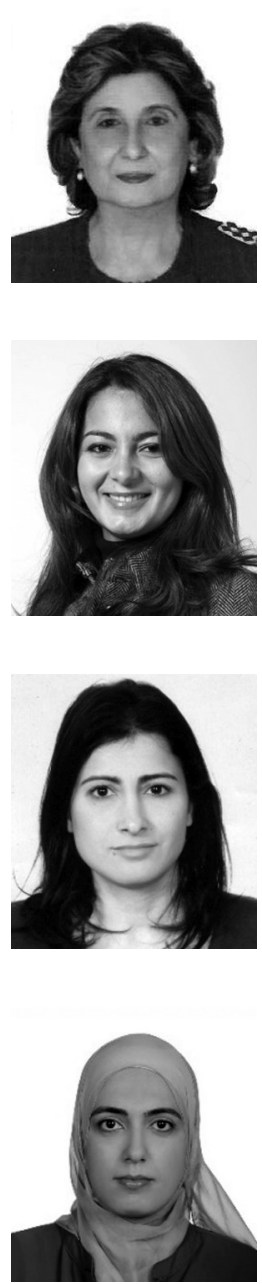

Ibtihal Y. El-Bastawissi has been the dean of BAU's Faculty of Architecture-Design and Built Environment since 2015. Before that, she served as the vice dean of graduate studies and research at the Faculty of Engineering of the Alexandria University. She received her PhD in 1989 jointly with Liverpool University. She developed strategic tourism plans in collaboration with governmental and international agencies. She is currently representing BAU as the institutional coordinator for SDG 9 of the International Association of Universities (IAU) thematic cluster on Higher Education and Research for Sustainable Development (HESD).

Rokia Raslan is vice dean for innovation and enterprise at the Bartlett Faculty of the Built Environment at University College London (UCL) and associate professor in building performance simulation at the UCL Institute for Environmental Design and Engineering (UCL IEDE). She trained as an architect specialising in environmental and energy-efficient building design and her research interests include the analysis and monitoring of the energy performance of the built environment and application of energy policy and legislation.

Hiba Mohsen is an assistant professor at Beirut Arab University, Faculty of Architecture-Design and Built Environment. Her research and teaching interests involve environmental design, sustainable urban design and planning, urban modelling, and simulation. Hiba holds a PhD in urban design and planning with a dissertation titled Optimising Beirut Neighbourhood Microclimate Through Green Infrastructure: A 3D Urban Modelling Approach. In addition to her academic experience, Hiba has over 15 years of architectural experience working on local and regional design projects.

Hoda Zeayter is attending a PhD programme in architecture at Beirut Arab University, Faculty of Architecture-Design and Built Environment, with a thesis titled Preventive Conservation of Historic Buildings by Controlling Their Hygrothermal Behavior in Mediterranean Climate. Interested in the innovation methods applied in the conservation field, her research focuses on the preservation of the historic sandstone envelope of the Lebanese Built Heritage and the changes that occurred on its acclimatisation. She is currently a teaching assistant at the Faculty of Architecture. 